1 Cenozoic advance of the East Asian monsoon promoted carbon dioxide

2 consumption by weathering of the Mg-rich southern China upper crust

3 Yibo Yang ${ }^{1,2 *}$, Albert Galy ${ }^{3}$, Xiaomin Fang1, 2, 4*, Christian France-Lanord ${ }^{3}$,

4 Shimming Wan ${ }^{5,6}$, Rongsheng Yang ${ }^{1,3}$, Jian Zhang ${ }^{1}$, Ran Zhang ${ }^{7}$, Song Yang ${ }^{8}$, Yunfa

$5 \quad$ Miao $^{9}$, Chengcheng Ye $^{1}$, Yudong Liu ${ }^{1,4}$

$7{ }^{1}$ Key Laboratory of Continental Collision and Plateau Uplift, Institute of Tibetan

8 Plateau Research, Chinese Academy of Sciences, Beijing 100101, China

$9 \quad{ }^{2}$ CAS Center for Excellence in Tibetan Plateau Earth Sciences, Beijing 100101, China

$10{ }^{3}$ Centre de Recherches Pétrographiques et Géochimiques, UMR7358, CNRS -

11 Université de Lorraine, 54500 Vandoeuvre les Nancy, France

$12{ }^{4}$ University of Chinese Academy of Sciences, Beijing 100049, China

$13{ }^{5}$ Key Laboratory of Marine Geology and Environment, Institute of Oceanology,

14 Chinese Academy of Sciences, Qingdao 266071, China

$15{ }^{6}$ Function Laboratory for Marine Geology, National Oceanography Laboratory, 16 Qingdao 266061, China

$17{ }^{7}$ Climate Change Research Center, Institute of Atmospheric Physics, Chinese 18 Academy of Sciences, Beijing 100029, China

$19{ }^{8}$ Key Laboratory of Tibetan Environment Changes and Land Surface Processes, 20 Institute of Tibetan Plateau Research, Chinese Academy of Sciences, Beijing 100101, 21 China

$22{ }^{9}$ Key Laboratory of Desert and Desertification, Northwest institute of 23 Eco-Environment and Resources, Chinese Academy of Sciences, Lanzhou,730000, 24 China

$25 *$ Corresponding authors: yangyibo@itpcas.ac.cn (Y. Yang) or fangxm@itpcas.ac.cn 26 (X. Fang)

\title{
27 Abstract
}

The Oligocene-Miocene boundary climatic reorganization linked to the northward advance of the East Asian monsoon in subtropical China is a potentially important but poorly constrained atmospheric $\mathrm{CO}_{2}$ sink. Here, we performed a first-order estimate 31 of the difference in $\mathrm{CO}_{2}$ consumption induced by silicate chemical weathering and 32 organic carbon burial in subtropical China related to this monsoon advance. The results highlight the significant role of weathering of the $\mathrm{Mg}$-rich upper continental crust in East China that would contribute significantly to the rise in the $\mathrm{Mg}$ content of 
the ocean during the Neogene. Our results show that an increase in $\mathrm{CO}_{2}$ consumption by silicate weathering varies between $\sim 1 \%$ and $15 \%$ of the current global continental silicate sink with an $\sim 60 \%$ contribution of $\mathrm{Mg}$-silicate weathering since the late Oligocene but a negligible increase in the global organic carbon burial $(<3.5 \%)$. The carbon impact of the northward advance of the East Asian monsoon is therefore significant but strongly related to the Mg-rich nature of the crust affected by such climatic change. Further modelling work indicates that the uplift of the northern Tibetan Plateau plays a key role in this monsoon advance. Our study thus suggests that the uplift of the Himalayas-Tibetan Plateau can lead to indirect modification of the carbon cycle and the global climate by changing the regional hydrological cycle in areas of East Asia that are tectonically inactive in addition to the direct impact of high erosion and organic carbon burial along the orogenic belt in South Asia.

Keywords: Tibetan Plateau; Late Oligocene; silicate weathering; carbon cycle; oceanic Mg cycle

\section{Introduction}

Atmospheric $\mathrm{CO}_{2}$ consumption by silicate weathering and organic carbon burial are the sinks that control atmospheric $\mathrm{CO}_{2}$ levels over geological timescales. Complex feedback mechanisms between climate and tectonics led to a hypothesis that the uplift of the Himalayas-Tibetan Plateau (TP) was a primary driver of Cenozoic atmospheric $\mathrm{CO}_{2}$ decline and global cooling predominantly through accelerating silicate chemical weathering in the India-Asia collision zone (Raymo and Ruddiman et al., 1992; Kump et al., 2000), while debated (e.g., Blum et al., 1998), and through effective burial of organic carbon in the nearby Bengal Fan in South Asia (France-Lanord and Derry, 1997; Galy et al., 2007; Lee et al., 2019). However, orogenic uplift also contributed to the increase in monsoonal rainfall by the expansion of the East Asian monsoon and, as such, might have extensive control over the geological carbon cycle by enhancing silicate chemical weathering and/or burial of organic carbon in East Asia, namely, outside the Bay of Bengal (Fig. 1).

The modern East Asian climatic pattern is likely to have been established at the Oligocene-Miocene boundary with an arid zone restricted to Northwest China, in contrast to a relatively broad belt of aridity stretching across China from west to the east during the Palaeogene (Fig. 1, Guo et al., 2008; Sun and Wang, 2005;). The onset of the East Asian monsoon was recently proposed to be during the Eocene, but monsoonal activities were restricted to regions not exceeding the far south of China 
(e.g., Licht et al., 2014; Spicer et al., 2016; Xie et al., 2020). Monsoon penetration into modern arid Northwest China may have extensively occurred only from the latest early Oligocene to early Miocene, as suggested by fossil evidence (Guo et al., 2008; Miao et al., 2013; Song et al., 2019; Sun and Wang, 2005). This reorganization of the climate system around the Oligocene-Miocene boundary from arid to modern, monsoon-like humid in this broad region involves a total area of $\sim 3.2 \times 10^{6} \mathrm{~km}^{2}$ (Fig. 1). The increase in rainfall due to the monsoon advance over such a broad region is thus expected to not only enhance silicate weathering but also accelerate terrestrial organic carbon production. In particular, weathering of Mg-enriched Yangtze and North China cratons in East China (Gao et al., 1991, 1998), which makes up the majority of the area affected by climatic reorganization around the

81 Oligocene-Miocene boundary (Fig. 1b), could yield a more significant atmospheric $\mathrm{CO}_{2}$ sink than the weathering of Mg-depleted Himalayan terranes (e.g., France-Lanord and Derry, 1997). To test this hypothesis, we performed a first-order estimate of the changes in $\mathrm{CO}_{2}$ consumption flux from silicate weathering and organic carbon burial through the Palaeogene-Neogene boundary using the chemistry of sediments in the South China Sea (SCS) and soils in East China regions.

\section{Material and methods}

\subsection{Quantifying carbon dioxide consumption by silicate weathering}

Quantification of the release of soil base cations in silicate weathering can be done only by normalizing their abundances to that of an immobile element, and we used $\mathrm{Al}$ since other immobile elements, such as $\mathrm{Ti}$, are more sensitive to changes in the composition of the regolith (e.g., Ti is relatively enriched in mafic rocks in the upper crust of eastern China, Gao et al., 1991). Given that $\mathrm{Al}$ is an immobile element during bedrock weathering, the $\mathrm{CO}_{2}$ consumption $\left(\mathrm{mol} \cdot \mathrm{kg}^{-1}\right)$ due to weathering of silicates in bedrock for a given base cation $\left(\Delta \mathrm{X}_{0}\right)$ can be estimated by:

$\Delta \mathrm{X}_{0}=\left([\mathrm{X}]_{\text {bedrock }}-[\mathrm{Al}]_{\text {bedrock }} /[\mathrm{Al}]_{\text {soil }} \times[\mathrm{X}]_{\text {soil }}\right) / \mathrm{MX}_{\mathrm{X}} \times 100$ where $[X]$ shows the concentration (\%) of element $X$ measured in soil and bedrock and $\mathrm{M}$ is the molar mass for a given element $\mathrm{X}$. The overall $\mathrm{CO}_{2}$ consumption on geological timescales $(>1 \mathrm{Myr})$ by silicate weathering $\left(\mathrm{C}_{\text {sil }}\right)$ between bedrock and soil can thus be estimated by the overall difference of soil base cations: assuming that all the alkalinity equivalent to $\mathrm{Mg}^{2+}$ and $\mathrm{Ca}^{2+}$ lost from silicate minerals ultimately precipitates as marine carbonate, that only a fraction of the alkalinity is associated with alkalis $\left(20 \%\right.$ for $\mathrm{K}^{+}$and $30 \%$ for $\left.\mathrm{Na}^{+}\right)$and that there is no "reverse 
weathering" as a sink for these base cations in marine settings (France-Lanord and Derry, 1997).

The change in $\mathrm{CO}_{2}$ consumption by silicate weathering $\left(\Delta_{\text {sil }}\right)$ can be evaluated by chemical differences between the soil in the study area after and before climatic reorganization. Then, the overall difference in average soil base cations between arid loess and humid red soils $\left(\Delta_{\text {sil }}\right)$ can be estimated as:

$$
\begin{aligned}
\Delta_{\text {sil }} & =\mathrm{C}_{\text {sil, a }}-\mathrm{C}_{\text {sil, b }} \\
& =\left(\Delta \mathrm{Ca} 0, \mathrm{a}-\Delta \mathrm{Ca}_{0, \mathrm{~b}}\right)+\left(\Delta \mathrm{Mg}_{0, \mathrm{a}}-\Delta \mathrm{Mg}_{0, \mathrm{~b}}\right)+0.10\left(\Delta \mathrm{K}_{0, \mathrm{a}}-\Delta \mathrm{K}_{0, \mathrm{~b}}\right)+0.15\left(\Delta \mathrm{Na}_{0, \mathrm{a}}-\Delta \mathrm{Na}_{0, \mathrm{~b}}\right) \\
& =\Delta \mathrm{Ca}+\Delta \mathrm{Mg}+0.10 \Delta \mathrm{K}+0.15 \Delta \mathrm{Na}
\end{aligned}
$$

where subscripts " $b$ " and "a" denote after and before the monsoon advance, respectively.

Because the tectonic setting in East China involving the assembly of the North China craton, Qinling Orogen and Yangtze craton formed prior to the Cenozoic (Zheng et al., 2013), we assumed that bedrock in East China exhibits the same composition between the Paleogene and the Neogene. Palaeogene arid soil composition is difficult to estimate due to the lack of data. However, a modern analogue of soil under semi-arid and arid settings could be the widespread eolian loess in northern China, which is typical of the well-mixed upper continental curst and is subject to only weak chemical weathering under arid climates (e.g., Gallet et al., 1996). Due to loess compositional homogeneity, we used the Xifeng (XF) Pleistocene loess (Fig. 1, Table S1) from northern China to represent lithosols and cambisols distributed in the modern arid/semi-arid climate (Fig. 2a). Loess can bear carbonates, but its composition after acetic acid leaching could be typical of soil silicate compositions in Palaeogene arid climates. However, loess, lithosols and cambisols from NW China might not have been formed from the same regolith as the weathered crust of southern East China. Thus, the estimates of related terms, e.g., $C_{\text {sil }}$ and $\Delta_{\text {sil }}$, could be biased. Such provenance bias is negligible except for $\Delta \mathrm{Mg}$ due to regional heterogeneity of Mg-bearing minerals in the upper crust rocks and the peculiar occurrence of a Mg-rich upper crust in East China (Gao et al., 1991, Gao et al., 1998).

Typical soils in humid subtropical China related to late Oligocene climatic reorganization are red earth and yellow earth, which account for $\sim 80 \%$ of red soils in China (He et al., 2004). Red and yellow earths are similar in composition but different in colour, as they contain different iron oxides (hematite and goethite, respectively). Here, we chose the average compositions of four red earth datasets and three yellow earth datasets that are well spaced and can represent widespread acrisols in subtropical China (Fig. 2a; Table S1). The red earth datasets included Quaternary red earth compositions along the Yangtze River (Dongting Lake, DTL, a regional 
investigation of red soils covering $1.4 \times 10^{4} \mathrm{~km}^{2}$, Zhang et al., 2007; Jiujiang, JJ, a 10.4 $\mathrm{m}$ thick red earth profile, and Xuancheng, XC, a 14 m thick red earth profile, Hong et al., 2013) and a red earth average across the entire South China (77 data of A horizon of soil profiles; CNEMC, 1990). The yellow earth datasets included Quaternary typical yellow earth compositions (Nanxiong, NX, a $2.4 \mathrm{~m}$ thick yellow earth profile; Tianyang, TY, a $4.2 \mathrm{~m}$ thick yellow earth profile) around the southern boundary of the subtropical zone (Table S1) and a yellow earth average across the entire South China (37 data of A horizon of soil profiles across South China, CNEMC, 1990). Gleysols from the lower reaches of the Yangtze and Yellow Rivers were not considered here because they are cultivated soils.

In our study, the NX and TY yellow earth samples were oven-dried, ground into powder, and leached by diluted acetic acid. Diluted acetic acid leaching will introduce few $\mathrm{Ca}$ from silicates. The residues were digested by pressurized acid digestion using a mixture of $\mathrm{HNO}_{3} / \mathrm{HF}$. Major elements were analysed by inductively coupled plasma optical emission spectroscopy (ICP-OES, Leeman Labs Prodigy-H) at the Institute of Tibet Plateau Research, Chinese Academy of Sciences. Concentrations of all elements were normalized to the weight of the bulk leached residues. Replicate analyses of samples showed relative standard deviations of $<2 \%$. Except NX and TY yellow earth samples with acetic leaching residues, other data used here are whole rock data. Since few amounts of carbonates exist in such low-pH environments in south China, the two types of data are comparable.

163 To impart constraints on changes in soil silicate composition in response to global cooling and regional climate variability during the Neogene, we also estimated $\Delta_{\text {sil }}$ variability using the average compositions of diluted acetic acid leached sediments of

166 Ocean Drilling Program (ODP) site 1146 in the SCS (Fig. 1a). These sediments represent an average of the eroded silicates from southern East China (e.g., Liu et al. 2003). Considering the variation in silicate weathering intensity, two stages have been defined at 15-19 $\mathrm{Ma}(\mathrm{SCS} 15-19 \mathrm{Ma})$ and 0-5 Ma (SCS 0-5 Ma), corresponding to strong and weak silicate weathering intensity stages, respectively (Wan et al., 2010).

171 We used these two stages as the Neogene composition and, similar to our soil 172 approach, compared it to the arid loess in North China.

\subsection{Quantifying carbon dioxide consumption by organic carbon burial}

Changes in the organic carbon burial $\left(\Delta_{\mathrm{oc}}\right)$ after and before climatic reorganization can be quantified by measuring the difference in the terrestrial organic 
177 directly evaluated using data from marginal sea sediments because it is difficult to 178 distinguish terrestrial and marine contributions to bulk organic carbon. When $\Delta_{\text {oc }}$ was 179 directly evaluated using marginal sea sediments, a dominance of marine organic 180 material was revealed (Shipboard Scientific Party, 2000). However, by analogy with 181 the findings in the Bay of Bengal (e.g., Galy et al., 2007; Lee et al. 2019), we assumed 182 that $\Delta_{\mathrm{oc}}$ is principally controlled by terrestrial organic carbon production and burial 183 efficiency in marine sediments, and $\Delta_{\mathrm{oc}}$ could be simply estimated as:

$184 \Delta_{\mathrm{oc}}=M_{\mathrm{a}} \times f_{\mathrm{a}}-M_{\mathrm{b}} \times f_{\mathrm{b}}$

185 where $M$ denotes organic matter content in soils, $f$ denotes the organic carbon burial 186 efficiency (percentage of organic carbon preserved in sediments), and the subscripts 187 "a" and "b" denote after and before the monsoon advance, respectively.

\subsection{Quantifying monsoon rainfall in response to tectonic uplift}

To further constrain the orogenic uplift effect on the precipitation change in monsoon-influenced region in East China, we used a climate model to test precipitation differences between the modern topography and Palaeogene topography. Boundary conditions of the model corresponded to a change in topography only in the northern part of the TP since 1) uplift of this region exhibited a profound impact on the East Asian monsoon (Liu et al., 2015) and 2) the major uplift-related topographic change in this region occurred over the Neogene (e.g., Tapponnier et al., 2001; Lin et al., 2020). Two experiments were conducted with different topographies. The first utilized modern conditions with the present topography. In the second experiment, the northern TP was removed according to the uplift history of the TP (Tapponnier et al., 2001), which represents the Oligocene condition. Thus, the difference between the experiments gives the climatic effects of the rise of the northern part of the TP.

We employed the Community Earth System Model version 1.2.2 (CESM1.2.2) developed by the National Center of Atmospheric Research (NCAR). This model consists of atmosphere, ocean, land, river runoff, sea ice, land ice, and ocean wave components that interact with each other through a coupler. However, only the first 5 components were active in the model used in this study (see details in Zhang et al., 2019). Both experiments are run with a $\mathrm{CO}_{2}$ concentration of 560 ppmv, which is

207 higher than the present concentration and represents the late Oligocene level based on

208 various proxies (Beerling and Royer, 2011). The concentrations of 209 chloro-fluoro-carbon (CFCs) were set to 0 , and those of $\mathrm{CH}_{4}$ and $\mathrm{N}_{2} \mathrm{O}$ were set 760 $210 \mathrm{ppbv}$ and $270 \mathrm{ppbv}$, respectively. All the other conditions, including $\mathrm{O} 3$ and aerosol 211 concentrations, the solar constant and orbital parameters, were set to preindustrial 
212 conditions. Both experiments were run for 1700 model years, which is long enough

213 for the atmosphere and ocean surface layer to reach quasi-equilibrium. The last 50

214 years of data from each experiment were analysed and presented in this study.

\section{The magnitude of silicate weathering and organic carbon burial change}

\section{$216 \quad 3.1$ Silicate alteration and Mg contribution}

217 The results of $\mathrm{C}_{\text {sil }}$ show a high contribution of $\mathrm{Ca}$-bearing mineral weathering

$218(\Delta \mathrm{Ca} 0)$ in all chosen weathered products in humid subtropical China and arid northern

219 China but a distinct pattern of $\mathrm{Mg}$ contribution $\left(\Delta \mathrm{Mg}_{0}\right)$ between the two regions (Fig.

$2203 \mathrm{a}) . \mathrm{C}_{\text {sil }}{ }^{*}$, defined as $\mathrm{C}_{\text {sil }}{ }^{*}=\mathrm{C}_{\text {sil }}-\Delta \mathrm{Mg}_{0}$, could be used to account for $\mathrm{CO}_{2}$ consumption

221 by the chemical weathering of $\mathrm{Ca}-\mathrm{Na}-\mathrm{K}$ silicate minerals only (mainly feldspar).

222 There are significant differences between $\mathrm{C}_{\text {sil }}{ }^{*}$ and $\mathrm{C}_{\text {sil }}$ for the SCS sediments, the

223 yellow and red earths, but there are few differences for the XF loess. This contrast

224 suggests a dominant climate-induced weathering behaviour that is characterized by a

225 greater depletion of $\mathrm{Mg}$ and $\mathrm{Ca}$ in humid subtropical China than in arid northern

226 China. This climate-induced weathering contrast can also be supported by the results

227 of $\Delta_{\text {sil }}$ that can be regarded as the composition difference of weathering products

228 between intense and weak weathering regimes (Fig. 3b). The detail of the contribution

229 from each cation shows decreasing $\mathrm{CO}_{2}$ consumption values with

$230 \Delta \mathrm{Mg}>\Delta \mathrm{Ca}>\Delta \mathrm{Na}>\Delta \mathrm{K}$ (Fig. 3b, Table $\mathrm{S} 2$ ), in line with the relative mineral stability

231 during weathering (e.g., Mg-bearing minerals weather the fastest, followed by

232 Ca-feldspar, Na-feldspar, and finally K-feldspar). Furthermore, the $\Delta_{\text {sil }} / C_{\text {sil }}$ ratios yield

233 a mean of $\sim 50 \%$ for SCS sediments and $\sim 60 \%$ subtropical soils, suggesting a

234 dominant cation yield by intense weathering in humid South China.

The $\Delta_{\text {sil }}$ pattern is suitable for displaying silicate alteration related to late 236 Oligocene monsoon advance. Similarly, $\Delta_{\text {sil }}{ }^{*}$, defined as $\Delta_{\text {sil }}{ }^{*}=\Delta_{\text {sil }}-\Delta \mathrm{Mg}$, was used to 237 account for $\mathrm{CO}_{2}$ consumption by the chemical weathering of $\mathrm{Ca}-\mathrm{Na}-\mathrm{K}$ silicate 238 minerals only (mainly feldspar). The difference between $\Delta_{\text {sil }}$ and $\Delta_{\text {sil }}{ }^{*}$ indicates that the 239 relative contribution of $\Delta \mathrm{Mg}$ is always $>60 \%$ (Table S3). $\Delta_{\text {sil }}{ }^{*}$ ranged from 0.12 to $240 \quad 0.16 \mathrm{~mol} \cdot \mathrm{kg}^{-1}$ for SCS sediments and from 0.18 to $0.22 \mathrm{~mol} \cdot \mathrm{kg}^{-1}$ for modern soils (Fig. 241 3b). Differences for the SCS sediments (19-15 Ma vs. 5-0 Ma) regarding different 242 silicate weathering intensities (Table S3) suggest that the variability of Neogene 243 climate/provenance for $\Delta_{\text {sil }}{ }^{*}$ and $\Delta_{\text {sil }}$ is probably within $20-30 \%$. These $\Delta_{\text {sil }}{ }^{*}$ values are 244 comparable to $\mathrm{CO}_{2}$ consumption by silicate weathering in ODP 116 sediments in the 245 Bengal Fan (Fig. 1), where $\mathrm{CO}_{2}$ consumption $\left(\mathrm{C}_{\text {sil }}\right)$ is between $0.17 \mathrm{~mol} \mathrm{~kg}^{-1}$ for 246 illite-chlorite sediments with no contribution from $\Delta \mathrm{Mg}$ and $0.23 \mathrm{~mol} \cdot \mathrm{kg}^{-1}$ for 
smectite-kaolinite sediments with a contribution of only $\sim 0.03 \mathrm{~mol} \cdot \mathrm{kg}^{-1}$ by $\Delta \mathrm{Mg}$ (Fig. 3a; France-Lanord and Derry, 1997). This suggests a comparable magnitude of $\mathrm{CO}_{2}$ consumption by silicate alteration except for $\mathrm{Mg}$ for both regions.

Overall, the key difference in monsoon-influenced silicate weathering in subtropical China is the dominant effect of weathering of Mg-bearing silicates, which is likely related to the higher $\mathrm{Mg}$ concentrations in the Yangtze and Northern China cratons (e.g., Gao et al., 1991; Gao et al., 1998) than in the average upper continental crust (UCC, e.g., Rudnick and Gao, 2014) or the Himalayan crust (e.g., France-Lanord and Derry, 1997). For example, the relatively low $\Delta \mathrm{Mg}$ contribution $<$ $\sim 0.03 \mathrm{~mol} \cdot \mathrm{kg}^{-1}$ in South Asia corresponds to High Himalayan crystalline rocks with low $\mathrm{MgO}$ (1.76\%, France-Lanord and Derry, 1997). Further, the erosional products have higher $\mathrm{MgO}$ contents (with a mean of $3.12 \%, \mathrm{n}=30$ ) for the fine-grained silicate sediments in the Yangtze River (He et al., 2015) than those in the XF loess (2.76\%)

260 (Table S1). These observations conform to that East China (carbonate-free 261 composition), compared with other terranes (e.g., the Canadian shield), contains large proportions of unmetamorphosed supracrustal units that are considered to have, on average, higher proportions of mafic volcanics (Gao et al., 1998; Rudnick and Gao, 2004). Generally, the high $\Delta \mathrm{Mg}$ contribution can result from the facts that 1) Mg-rich upper crust rocks will be strongly depleted during soil silicate weathering and 2) the upper crust that experienced the intensification of climate-induced weathering is a $\mathrm{Mg}$-rich portion. Such low $\mathrm{MgO}$ content preserved in red and yellow earths under a humid climate (Fig. 1) that dominated the Mg-rich upper crust in East China thus suggests a significantly higher Mg loss by weathering of the East China upper crust affected by late Oligocene climatic reorganization.

\subsection{Organic carbon burial}

To estimate $\Delta_{\mathrm{oc}}$, we first qualified the organic carbon burial efficiency, $f$. It is suggested that a high $f$ value mainly results from high erosion/rapid deposition systems (Blair and Aller, 2012), e.g., the Bengal Fan (Galy et al., 2007) and steep mountain rivers (Hilton et al., 2011). The Neogene monsoon climate in subtropical China can generate a large delivery of suspended sediments to the ocean in comparison with that in the Palaeogene (e.g., Métivier et al., 1999; Clift et al., 2004).

278 Since the Yangtze River is the major carrier of sediments in subtropical China, we 279 conservatively assumed that both $f_{\mathrm{a}}$ and $f_{\mathrm{b}}$ were $\sim 30 \%$, the $f$ value for the modern 280 Yangtze River (Blair and Aller, 2012), which yielded a minimum estimation of $\Delta_{\mathrm{oc}}$.

281 The modern soil organic carbon content is $0.8-1.8 \%$ in most subtropical China 
and is $0.4-0.8 \%$ in arid-semi-arid China for surface soil horizons (0 to $30 \mathrm{~cm}$ ) (Fig. 2b). The area-weighted mean values are $1.3 \pm 0.6 \%$ (excluding cultivated soils in East China) and $0.7 \pm 0.3 \%$ for humid subtropical China and arid North China, respectively.

285 Given a mean of $\sim 0.2 \%$ for the fossil carbon content inherited from parent rock in SE 286 Asia (France-Lanord and Derry, 1997; Hilton et al, 2011) and assuming its burial 287 efficiency of $100 \%, M_{\mathrm{a}}$ and $M_{\mathrm{b}}$ were assumed to be 0.89 and $0.39 \mathrm{~mol} \cdot \mathrm{kg}^{-1}$, 288 respectively, and together yielded a $\Delta_{\mathrm{oc}}$ of $0.15 \mathrm{~mol} \mathrm{C} \cdot \mathrm{kg}^{-1}$. This $\Delta_{\mathrm{oc}}$ is less than $\Delta_{\text {sil }}$, 289 exhibiting a mean value of $0.60 \mathrm{~mol} \cdot \mathrm{kg}^{-1}$ in subtropical China, which contrasts with 290 the Himalayas, where the $\Delta_{\mathrm{oc}}$ is much larger than $\Delta_{\text {sil }}$ (France-Lanord and Derry, 291 1997).

\section{Discussion}

\subsection{Erosion rate related to the late Oligocene monsoon advance}

Assessing the role of monsoon advance-induced silicate weathering and organic carbon burial in the context of the global budget requires an historical estimation of the volume of the crust subjected to erosion. We reconstructed this temporal variation in erosion flux as described in the following paragraphs.

In modern settings, the physical erosion of subtropical China is highly variable with ${ }^{10} \mathrm{Be}$-based erosion rates from $20-50 \mathrm{~mm} \cdot \mathrm{kyr}^{-1}$ in low relief areas to $700-900$

$300 \mathrm{~mm} \cdot \mathrm{kyr}^{-1}$ in steep, landslide-dominated mountain terrane (Chappel et al., 2006). The 301 drainage basin of the Yangtze River is mainly located within the study area (Fig. 1a) and accounts for $59 \%$ of the study area. In addition, the Yangtze River drains variable landscapes and climates and is thus likely to provide an area-averaged erosion rate for the whole studied area. Therefore, we assumed that the physical erosion of subtropical

305 China (total area of $\sim 3.2 \times 10^{6} \mathrm{~km}^{2}$ ) is $\sim 800 \times 10^{6} \mathrm{t} \cdot \mathrm{yr}^{-1}$ by extrapolation of $480 \times 10^{6}$ $\mathrm{t} \cdot \mathrm{yr}^{-1}$ for the Yangtze River (Milliman and Syvitski, 1992).

We then assumed that the long-term variations in erosion flux related to subtropical China could generally scale with the temporal variations in the sediment budget around the East China marginal basins. The existing Cenozoic sediment budgets for the major basin systems of East Asia have yielded distinct long-term 311 variations (Clift, 2004; Métivier et al., 1999). The results of Clift et al. (2004) 312 including the Pearl River, East China Sea and Bohai Bay display different long-term 313 variations with peaks of sedimentation in the Mid-Miocene and Quaternary (Clift et 314 al., 2004; Fig. 4a). Métivier et al. (1999) showed a monotonous increase in the 315 sedimentation rate in the East China Platform, which includes the East China 316 Sea/North Taiwan, Okinawa, Yellow Sea and Bohai Bay (Fig. 4a). Clarification of 
317 both variations is out of the aim and scope of this study; thus, we used our modern

318 estimate of erosion flux to multiply the two relative variations of sediment discharges 319 to construct two records of erosion flux related to subtropical China climatic 320 reorganization since the late Oligocene (Fig. 4a).

\subsection{Mg flux linked to the monsoon advance}

The Mg flux variation linked to the monsoon advance from silicate weathering,

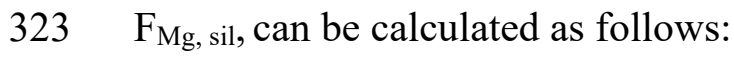

$324 \mathrm{~F}_{\mathrm{Mg}, \mathrm{sil}}=\mathrm{E}_{\mathrm{a}} \times \Delta \mathrm{Mg}_{0, \mathrm{a}}-\mathrm{E}_{\mathrm{b}} \times \Delta \mathrm{Mg}_{0, \mathrm{~b}}$

325 where $\mathrm{E}$ is sediment yield $\left(\mathrm{kg} \cdot \mathrm{yr}^{-1}\right)$ and it corresponds to our reconstructed erosion 326 flux (Figs. $4 \mathrm{a}$ ). $\Delta \mathrm{Mg}_{0, \mathrm{~b}}$ is $0.03 \mathrm{~mol} \cdot \mathrm{kg}^{-1}$, identical to XF loess (Fig. 3a). $0.45 \mathrm{~mol} \cdot \mathrm{kg}^{-1}$

327 for $\Delta \mathrm{Mg}_{0, \mathrm{~b}}$ is the mean of $\Delta \mathrm{Mg}_{0}$ for SCS sediments and red soils in subtropical China 328 (Fig. 3).

329 In addition, the sedimentary cover of East China bears a significant amount of 330 dolostone lithology (e.g., Gao et al., 1991). The Neogene intensification of the 331 weathering of that area would also have dissolved a relatively large amount of $332 \mathrm{Mg}$-rich carbonate, further delivering $\mathrm{Mg}$ to the oceanic cycle. $\mathrm{The} \mathrm{Mg}$ and $\mathrm{Ca}$ 333 concentrations related to carbonate in the eastern China upper crust can be estimated 334 by the comparison of the CEC upper crust compositions with and without carbonate 335 (Gao et al., 1998). Assuming $\mathrm{Si}$ resides in only silicates, then the $\mathrm{Mg}$ molar 336 concentration in carbonate $\left([\mathrm{Mg}]_{\mathrm{carb}}, \mathrm{mol} \cdot \mathrm{kg}^{-1}\right)$ can be estimated as follows:

$337 \quad[\mathrm{Mg}]_{\text {carb }}=[\mathrm{Mg}]_{\text {bulk }}-[\mathrm{Mg}]_{\text {sil }} /[\mathrm{Si}]_{\text {bulk }} \times[\mathrm{Si}]_{\text {sil }}$

338 where the subscripts "bulk" and "sil" denote element molar concentrations the CEC

339 upper crust compositions with and without carbonates, respectively. The estimated $340[\mathrm{Mg}]_{\text {carb }}$ is $0.37 \mathrm{~mol} \cdot \mathrm{kg}^{-1}$, and $[\mathrm{Ca}]_{\text {carb }}$ is $0.80 \mathrm{~mol} \cdot \mathrm{kg}^{-1}$, as calculated by the same 341 approach. The molar $\mathrm{Mg} / \mathrm{Ca}$ ratio in carbonate in eastern China is 0.46 , which 342 indicates that approximately $50 \%$ of carbonate minerals are dolomite, given a molar $343 \mathrm{Mg} / \mathrm{Ca}$ ratio of 0.08 for calcite (a lower limit of average post-Archean carbonates in 344 East China, Gao et al., 1991) and a molar $\mathrm{Mg} / \mathrm{Ca}$ ratio of 1 for dolomite, supporting 345 the above observation of a dolostone-rich lithology in East China. Since dolomite is 346 hard to dissolve in arid and semi-arid settings (e.g., in arid NW China), we assumed 347 that only calcite dissolves in arid settings before the monsoon advance and that both 348 calcite and dolomite dissolve in humid settings after the monsoon advance. The $\mathrm{Mg}$ 349 flux variation linked to the monsoon advance through carbonate weathering, $\mathrm{F}_{\mathrm{Mg}}$, sil, 350 can be calculated as follows:

$351 \quad \mathrm{~F}_{\mathrm{Mg}, \text { carb }}=\mathrm{E}_{\mathrm{a}} \times[\mathrm{Mg}]_{\mathrm{carb}, \mathrm{a}}-\mathrm{E}_{\mathrm{b}} \times[\mathrm{Mg}]_{\mathrm{carb}, \mathrm{b}}$ 
Here, $[\mathrm{Mg}]_{\text {carb, a }}=0.37 \mathrm{~mol} \cdot \mathrm{kg}^{-1}$ corresponds to all $\mathrm{Mg}$ in carbonates (calcite and dolomite), and $[\mathrm{Mg}]_{\text {carb }, \mathrm{b}}=0.04 \mathrm{~mol} \cdot \mathrm{kg}^{-1}$ corresponds to $\mathrm{Mg}$ only in calcite with a molar $\mathrm{Mg} / \mathrm{Ca}$ ratio of 0.08 in the East China upper crust.

The reconstructed $\mathrm{Mg}$ release flux from weathering of silicate $\left(\mathrm{F}_{\mathrm{Mg}}\right.$, sil) and carbonate $\left(\mathrm{F}_{\mathrm{Mg} \text {, carb }}\right)$ related to the late Oligocene monsoon advance in East Asia shows that both fluxes account for their respective modern global flux 5-17\% based on erosion flux variation reported by Clift et al. (2004) and $\sim 1.5-17 \%$ based on erosion flux variation reported by Métivier et al. (1999) (Figs. 4b and 4c; the modern Mg flux from silicate weathering and carbonate weathering is $2-2.5 \times 10^{12} \mathrm{~mol} \cdot \mathrm{yr}^{-1}$ and $2-2.2 \times 10^{12} \mathrm{~mol} \cdot \mathrm{yr}^{-1}$, respectively, according to Higgins and Schrag, 2015). The $\mathrm{Mg}$ oceanic cycle during the Cenozoic is characterized by a rise in the $\mathrm{Mg}$ content in the ocean (e.g., Horita et al., 2002). The rise in the sea water Mg concentration from 38 $\mathrm{mmol} \cdot \mathrm{kg}^{-1}$ at $37 \mathrm{Ma}$ to $55.1 \mathrm{mmol} \cdot \mathrm{kg}^{-1}$ at present (Horita et al., 2002) requires an average rate of increase of $0.46 \mathrm{mmol} \cdot \mathrm{Ma}^{-1}$. The combined $\mathrm{Mg}$ flux of silicate and carbonate weathering related to the late Oligocene monsoon advance in East Asia accounts for a rate of increase of the seawater $\mathrm{Mg}$ concentration is $0.18-0.45$ $\mathrm{mmol} \cdot \mathrm{Ma}^{-1}$ based on erosion flux variation reported by Clift et al. (2004) and 0.05-0.46 mmol $\cdot \mathrm{Ma}^{-1}$ based on erosion flux variation reported by Métivier et al. (1999) since the late Oligocene. Our results clearly suggest that at least a significant portion of this rise in seawater $\mathrm{Mg}$ content corresponds to the weathering of Mg-silicates and dolomite-rich carbonates in East China rather than just changes in the amount of $\mathrm{Mg}$ removed from seawater (Higgins and Schrag, 2015).

\subsection{Carbon consumption flux linked to the monsoon advance}

Similar to the $\mathrm{Mg}$ flux estimation, the flux of long-term $\mathrm{CO}_{2}$ consumption by silicate weathering linked to the monsoon advance, $\mathrm{F}_{\text {sil }}$, can be calculated as follows:

378 where $\mathrm{C}_{\text {sil, a }}$ is $1.04 \mathrm{~mol} \cdot \mathrm{kg}^{-1}$, which is the mean of $\mathrm{C}_{\text {sil }}$ values for SCS sediments and red soils in subtropical China (Fig. 3); and $\mathrm{C}_{\text {sil, b }}$ is $0.43 \mathrm{~mol} \cdot \mathrm{kg}^{-1}$, identical to XF loess.

381 The reconstructed fluxes of long-term $\mathrm{CO}_{2}$ consumption by silicate weathering

382 ( $\mathrm{F}_{\text {sii) }}$ (Fig. 4e) account for 3-8\% of modern global flux of continental rock weathering

$383\left(8.7 \times 10^{12} \mathrm{~mol} \cdot \mathrm{yr}^{-1}\right.$, Gaillardet et al. 1999) based on the erosion flux variation by Clift 384 et al. (2004) and $\sim 1-9 \%$ by Métivier et al. (1999). It should be noted that $98 \%$ of our 385 estimated $\mathrm{F}_{\text {sil }}$ is attributed to $\mathrm{Ca}-\mathrm{Mg}$-silicate weathering since $\left(\Delta \mathrm{Mg}_{0}+\Delta \mathrm{Ca}_{0}\right)$ accounts 386 for $\sim 80 \% \mathrm{C}_{\text {sil }}$ of all samples (Fig. 3a). The modern estimate of $\mathrm{CO}_{2}$ consumption 
fluxes by Ca-Mg silicate is $5 \times 10^{12} \mathrm{~mol} \cdot \mathrm{yr}^{-1}$ (Gaillardet et al. 1999), which is $\sim 60 \%$ of the modern global flux of continental rock weathering. Thus, if only Ca-Mg-silicate weathering is considered, our estimated flux regarding weathering of $\mathrm{Ca}-\mathrm{Mg}$ silicate accounts for modern global flux of continental Ca-Mg-silicate weathering was 5-13\%

391 based on the given erosion flux variation reported by Clift et al. (2004) and $\sim 1-16 \%$

392 based on the erosion flux variation reported by Métivier et al. (1999).

393 In the same way, the flux of organic carbon burial linked to the monsoon advance,

$394 \quad \mathrm{~F}_{\mathrm{oc}}$, could be calculated as follows:

$395 \quad F_{\mathrm{oc}}=\mathrm{E}_{\mathrm{a}} \times M_{\mathrm{a}} \times f_{\mathrm{a}}-\mathrm{E}_{\mathrm{b}} \times M_{\mathrm{b}} \times f_{\mathrm{b}}$

396 The reconstructed organic carbon burial flux $\left(\mathrm{F}_{\mathrm{oc}}\right)$ shows $<3.5 \%$ of the modern global

397 flux of organic carbon for both erosion rate models (Fig. 4f). This organic carbon 398 burial flux is approximately $25 \%$ of the contemporary $\mathrm{CO}_{2}$ consumption by silicate 399 weathering (Fig. 4f), which also contrasts with the Himalayas, where the organic 400 carbon burial flux is much larger than that of silicate weathering (France-Lanord and 401 Derry, 1997).

402 The reconstructed long-term $\mathrm{CO}_{2}$ consumption fluxes by silicate weathering and 403 organic burial temporally vary, but the total amount $\left(\mathrm{F}_{\mathrm{sil}}+\mathrm{F}_{\mathrm{oc}}\right)$ is within the same order 404 as that in the Himalayas $\left(1.28 \times 10^{12} \mathrm{~mol}^{-} \mathrm{yr}^{-1}\right.$; France-Lanord and Derry, 1997). If the 405 Cenozoic long-term silicate weathering fluxes are relatively stable (Caves et al., 2016), 406 our reconstructed long-term $\mathrm{CO}_{2}$ consumption fluxes by silicate weathering and 407 organic burial can induce an imbalance in the geological carbon cycle. For long-term $408 \mathrm{CO}_{2}$ consumption fluxes by silicate weathering, weathering of $\mathrm{Mg}$ silicate $(\Delta \mathrm{Mg})$ 409 accounts for $64-72 \%$ of total $\mathrm{CO}_{2}$ consumption $\left(\Delta_{\text {sil }}\right)$, with a mean of $\sim 69 \%$ (Table S3). 410 Considering that the study region occupies $\sim 2 \%$ of the total continental area, our 411 study suggests a significant additional atmospheric $\mathrm{CO}_{2}$ sink by silicate weathering 412 when $\mathrm{Mg}$-bearing minerals are subjected to weathering in response to this climatic 413 reorganization since the late Oligocene. Such intensification of the weathering of the 414 Yangtze and North China cratons will also contribute to the required increasing land 415 surface reactivity during the Neogene (e.g., Kump and Arthur 1997; Caves et al. 2016; 416 Caves Rugenstein et al., 2019). Additionally, fast and congruent weathering of 417 dolomite-rich carbonate minerals $(\sim 10 \%)$ in the upper crust of humid subtropical 418 China after the monsoon advance may also contribute a long-term carbon sink by 419 aquatic photosynthesis (e.g., Liu et al., 2018).

\section{Implications for tectonic-climatic linkage}


magnitudes of $\sim 100->400 \mathrm{~mm}$, in response to topographic changes in the northern TP

423 (Fig. 7). Moreover, most of the annual precipitation increase occurred in summer, 424 especially over a large part of the Yangtze and North China cratons (Fig. 5), which 425 indicates that the East Asian monsoon climate system might have been established or 426 greatly strengthened. In summer, topographically elevated heating leads to 427 strengthening of the low over Asia, with which the anomalous southeasterly and/or 428 southwesterly winds mainly occur over East China (Fig. 5d). Thus, the modelling 429 results indicate that the East Asian summer monsoon circulation has been established 430 or is greatly stronger than it previously was. This strongly suggests that a 431 tectonic-climatic linkage induced by the uplift of the northern TP has played a major 432 role in the establishment of East Asian monsoon cycles in East China (e.g., Tada et al., 433 2016). The rapid late Oligocene-early Miocene uplift of the TP and a series of 434 concomitant tectonic events are evidenced by various studies of tectonic deformation 435 and volcanic rock emplacement ( $\mathrm{Lu}$ et al., 2018). The size of the India-Asia collision 436 thus had a prominent effect on the reorganization of the climatic patterns beyond the 437 collision zone with the northward advance of the East Asian monsoon in tectonically 438 inactive subtropical China, which, in turn, induced a globally significant silicate 439 weathering $\mathrm{CO}_{2}$ sink.

440 The study of orogenic effects on the global climate during the Cenozoic has 441 focused almost exclusively on the India-Asia collision zone (e.g., Raymo and 442 Ruddiman, 1992; France-Lanord and Derry, 1997). Our study suggests that the 443 significant rise in $\mathrm{CO}_{2}$ consumption induced by climatic changes and enhanced 444 erosion in both South and East Asia is an effect of the Indian-Asian collision and 445 uplift of the TP. This effect is characterized by an approximately equal order of 446 magnitude between the direct effect of the orogeny via enhanced carbon burial in 447 South Asia and the indirect effect that enhanced the weathering of Mg-rich silicate of 448 the Yangtze craton and surrounding terrane. The unusual nature of the exposed crust 449 in East China suggests that the tectonic impact on Cenozoic cooling via modulation of 450 the geological carbon cycle is particularly intense, and such forcing might not be fully 451 extrapolated to older global-scale orogeny. Our study thus illustrates how complex 452 perturbations of global climate and atmospheric $\mathrm{CO}_{2}$ levels by orogenic uplift can be 453 and how important the nature of the crust is not only involved in collisions but also 454 around collisions. This last point might have generated an imbalance in the global 455 carbon cycle since it is not involved in any tectonic feedback but is sensitive to 456 climate feedback, which may have contributed to the sharp atmospheric $\mathrm{CO}_{2}$ decline 457 during the late Oligocene and early Miocene transition (e.g., Beerling and Royer, 458 2011) and land reactivity that even regulates Neogene global cooling (Caves 
Rugenstein et al. et al., 2019). Although there are many unresolvable uncertainties, e.g., erosion fluctuations over short and long timescales (Métivier and Gaudemer, 1999; Clift et al., 2006), our study has provided a first-order estimate of the global geochemical cycle regarding carbon and magnesium linked to such complex tectonic-climate linkages.

\section{Acknowledgements}

This study was co-supported by the Second Tibetan Plateau Scientific Expedition and Research (STEP) program (Grant No: 2019QZKK0707), the Strategic Priority Research Program of the Chinese Academy of Sciences (Grant No: XDA20070201), the National Natural Science Foundation of China (Grant Nos., 41771236, 41620104002) and the Basic Science Center for Tibetan Plateau Earth System (CTPES, 41988101-01). Y. Yang is supported by the Youth Innovation Promotion Association (2018095) of the Chinese Academy of Sciences. The model simulations were performed on TianHe-2, thanks for the support of National Supercomputer Center in Guangzhou (NSCC-GZ).

Conflict of interest: The authors declare that they have no conflict of interest.

\section{References}

Beerling DJ, Royer DL. Convergent Cenozoic $\mathrm{CO}_{2}$ history. Nat Geosci 2011;4:418-420.

Blair NE, Aller RC. The Fate of Terrestrial Organic Carbon in the Marine Environment. Ann Rev Mar 2012;4:401-423.

Blum JD, Gazis CA, Jacobson AD, et al. Carbonate versus silicate weathering in the Raikhot watershed within the High Himalayan Crystalline Series. Geology 1998;26:411-414.

Caves JK, Jost AB, Lau KV, et al. Cenozoic carbon cycle imbalances and a variable silicate weathering feedback. Earth Planet Sc Lett 2016;450:152-163.

Caves Rugenstein JK, Ibarra D, von Blanckenburg F. Neogene cooling driven by land surface reactivity rather than increased weathering fluxes. Nature 2019;571:99-102.

Chappell J, Zheng H, Fifield K. Yangtse River sediments and erosion rates from source to sink traced with cosmogenic 10Be: Sediments from major rivers. Palaeogeogr Palaeoclimat Palaeoecol 2006;241:0-94.

Clift PD, Layne GD, Blusztajn J. Marine sedimentary evidence for monsoon 
strengthening, Tibetan uplift and drainage evolution in East Asia. In: Clift P, Wang P, Kuhnt W, Hayes DE, editors. Continent-Ocean Interactions within the East Asian Marginal Seas. 2004, p. 255-282.

Clift PD. Controls on the erosion of Cenozoic Asia and the flux of clastic sediment to the ocean. Earth Planet Sci Lett 2006;241:571-580.

CNEMC (China National Environmental Monitoring Centre). Background Values of Elements in Soils of China. Beijing: China Environmental Science Press; 1990.

France-Lanord C, Derry LA. Organic carbon burial forcing of the carbon cycle from Himalayan erosion. Earth Planet Sci Lett 1997;390:65-67.

Gaillardet J, Dupré B, Louvat $\mathrm{P}$, et al. Global silicate weathering and $\mathrm{CO}_{2}$ consumption rates deduced from the chemistry of large rivers. Chem Geol 1999;159:0-30.

Gaillardet J, Galy A. Himalaya-carbon sink or source? Science 2008;320:1727-1728.

Galy V, France-Lanord C, Beyssac O, et al. Efficient organic carbon burial in the Bengal fan sustained by the Himalayan erosional system. Nature 2007;450:407-410.

Galy V, Peucker-Ehrenbrink B, Eglinton T. Global carbon export from the terrestrial biosphere controlled by erosion. Nature 2015;521:204-207.

Gao S, Zhang B, Xie Q, et al. Average chemical compositions of post-Archean sedimentary and volcanic rocks from the Qinling Orogenic Belt and its adjacent North China and Yangtze Cratons. Chem Geol 1991;92:261-282.

Gao S, Luo T, Zhang B, et al. Chemical composition of the continental crust as revealed by studies in East China. Geochim Cosmochim Acta 1998;62:1959-1975.

Guo Z, Sun B, Zhang Z, et al. A major reorganization of Asian climate by the early Miocene. Clim Past 2008;4:153-174.

He M, Zheng H, Clift PD, et al. Geochemistry of fine-grained sediments in the Yangtze River and the implications for provenance and chemical weathering in East Asia. Prog Earth Planet Sci 2015;2:32.

He Z, Zhang M, Wilson MJ. Distribution and classification of red soils in China. In: Wilson MJ, He Z, Yang X, editors. The red soils of China. Springer Netherlands; 2004, p. 29-33.

Hilton RG, Galy A, Hovius N, et al. Efficient transport of fossil organic carbon to the ocean by steep mountain rivers: An orogenic carbon sequestration mechanism. Geology 2011;39:71-74.

Higgins JA, Schrag DP. The Mg isotopic composition of Cenozoic seawater-evidence for a link between $\mathrm{Mg}$-clays, seawater $\mathrm{Mg} / \mathrm{Ca}$, and climate. Earth Planet Sci Lett 2015;416:73-81. 
531 U-Pb Geochronology and Leaf Wax Hydrogen Isotope Studies. Tectonics 2020;39: 532 e2019TC005815.

533 Hong H, Wang C, Zeng K, et al. Geochemical constraints on provenance of the 534 mid-Pleistocene red earth sediments in subtropical China. Sediment Geol $535 \quad 2013 ; 290: 97-108$.

536 Horita J, Zimmermann H, Holland HD. Chemical evolution of seawater during 537 the Phanerozoic: Implications from the record of marine evaporites. Geochim 538 Cosmochim Acta 2002;66:733-3756,

539 Kump LR, Arthur MA. In: Ruddiman WF, editor. Tectonic Uplift and Climate 540 Change. Plenum Press; 1997, p. 399-426.

541 Kump LR, Brantley SL, Arthur MA. Chemical weathering, atmospheric $\mathrm{CO}_{2}$, 542 and climate. Annu Rev Earth Planet Sci Lett 2000;28:611-667.

543 Lee H, Galy V, Feng X, et al. Sustained wood burial in the Bengal Fan over the last 19 My. Proc Natl Acad Sci USA 2019;116:22518-22525.

Liang M, Guo Z, Kahmann AJ, et al. Geochemical characteristics of the Miocene 546 eolian deposits in China: Their provenance and climate implications. Geochem 547 Geophys Geosyst 2009;10:Q04004.

548 Licht A, Van Cappelle M, Abels HA, et al. Asian monsoons in a late Eocene 549 greenhouse world. Nature 2014;513:501-506.

550 Liu X, Sun H, Miao Y, et al. Impacts of uplift of northern Tibetan Plateau and 551 formation of Asian inland deserts on regional climate and environment. Quat Sci Rev $552 \quad 2015 ; 116: 1-14$.

553 Liu Z, Trentesaux A, Clemens SC, et al. Clay mineral assemblages in the northern 554 South China Sea: implications for East Asian monsoon evolution over the past 2 555 million years. Mar Geol 2003;201:133-146.

556 Liu Z, Macpherson G, Groves G, et al. Large and active $\mathrm{CO}_{2}$ uptake by coupled 557 carbonate weathering. Earth-Sci Rev 2018;182;42-49.

$558 \quad$ Lu H, Tian X, Yun K, et al. Convective removal of the Tibetan Plateau mantle 559 lithosphere by $26 \mathrm{Ma}$. Tectonophysics 2018;731:17-34.

560 Métivier F, Gaudemer Y. Stability of output fluxes of large rivers in South and 561 East Asia during the last 2 million years: implications on floodplain processes. Basin 562 Res 1999;11:293-303.

563 Miao Y, Wu F, Herrmann M, et al. Late early Oligocene East Asian summer 564 monsoon in the NE Tibetan Plateau: Evidence from a palynological record from the 565 Lanzhou Basin, China. J Asian Earth Sci 2013;75:46-57. 
Milliman JD, Syvitski PM. Geomorphic/tectonic control of sediment discharge to the ocean: the importance of small mountainous rivers. J Geol 1992;100:525-544.

Raymo ME, Ruddiman WF. Tectonic forcing of late Cenozoic climate. Nature 1992;359:117-122.

Rudnick RL, Gao S. Composition of the continental crust. Treatise on Geochemistry 2004;3:1-65.

Shipboard Scientic Party, Site 1146. In: Wang P, Prell WL, Blum P, et al. editors. Proc ODP Init Rep; 2000, 184.

Song B, Spicer RA, Zhang K, et al. Qaidam Basin leaf fossils show northeastern Tibet was high, wet and cool in the early Oligocene. Earth Planet Sci Lett 2020;537:116175.

Spicer RA., Yang J, Herman AB, et al. Asian Eocene monsoons as revealed by leaf architectural signatures. Earth Planet Sci Lett 2020;449: 61-68.

Sun X, Wang P. How old is the Asian monsoon system? - Palaeobotanical records from China. Journal of Tongji University, 2005;222:181-222.

Tada R, Zheng H, Clift PD. Evolution and variability of the Asian monsoon and its potential linkage with uplift of the Himalaya and Tibetan Plateau. Prog Earth Planet Sci 2016;3:4.

Tapponnier $\mathrm{P}, \mathrm{Xu} \mathrm{ZQ}$, Roger F, et al. Oblique stepwise rise and growth of the Tibet Plateau. Science 2001;294:1671-1677.

Wan S, Clift PD, Li A, et al. Geochemical records in the South China Sea: implications for East Asian summer monsoon evolution over the last $20 \mathrm{Ma}$. Geological Society of London, Special Publications. 2010;342:245-263.

Wieder WR, Boehnert J, Bonan GB, Langseth M. Regridded Harmonized World

590 Soil Database v1.2. Data set. Available on-line [http://daac.ornl.gov] from Oak Ridge

591 National Laboratory Distributed Active Archive Center, Oak Ridge, Tennessee, USA; 5922014.

593 Xie Y, Wu F, Fang X. A major environmental shift by the middle Eocene in southern China: Evidence from palynological records. Rev Palaeobot Palynol $2020 ; 104226$.

596 Zhang J, Liu Y, Fang X, et al. Large dry-humid fluctuations in Asia during the 597 Late Cretaceous due to orbital forcing: A modeling study. Palaeogeogr Palaeoclimat 598 Palaeoecol 2019;533:109230.

599 Zhang J, Lu J, Xing X, et al. Element geochemistry of laterite in the Dongting 600 Lake area, Hunan, China and its indicative significance. Geol Bull China 2007; $601 \quad 26: 1435-1444$.

602 Zhang R, Jiang D, Zhang Z, et al. Comparison of the climate effects of surface 
603 uplifts from the northern Tibetan Plateau, the Tianshan, and the Mongolian Plateau on 604 the East Asian climate. J Geophys Res-Atmos 2017;122: 7949-7970.

605 Zheng Y, Xiao W, Zhao G. Introduction to tectonics of China. Gondwana Res $6062013 ; 23: 1189-1206$.

607 


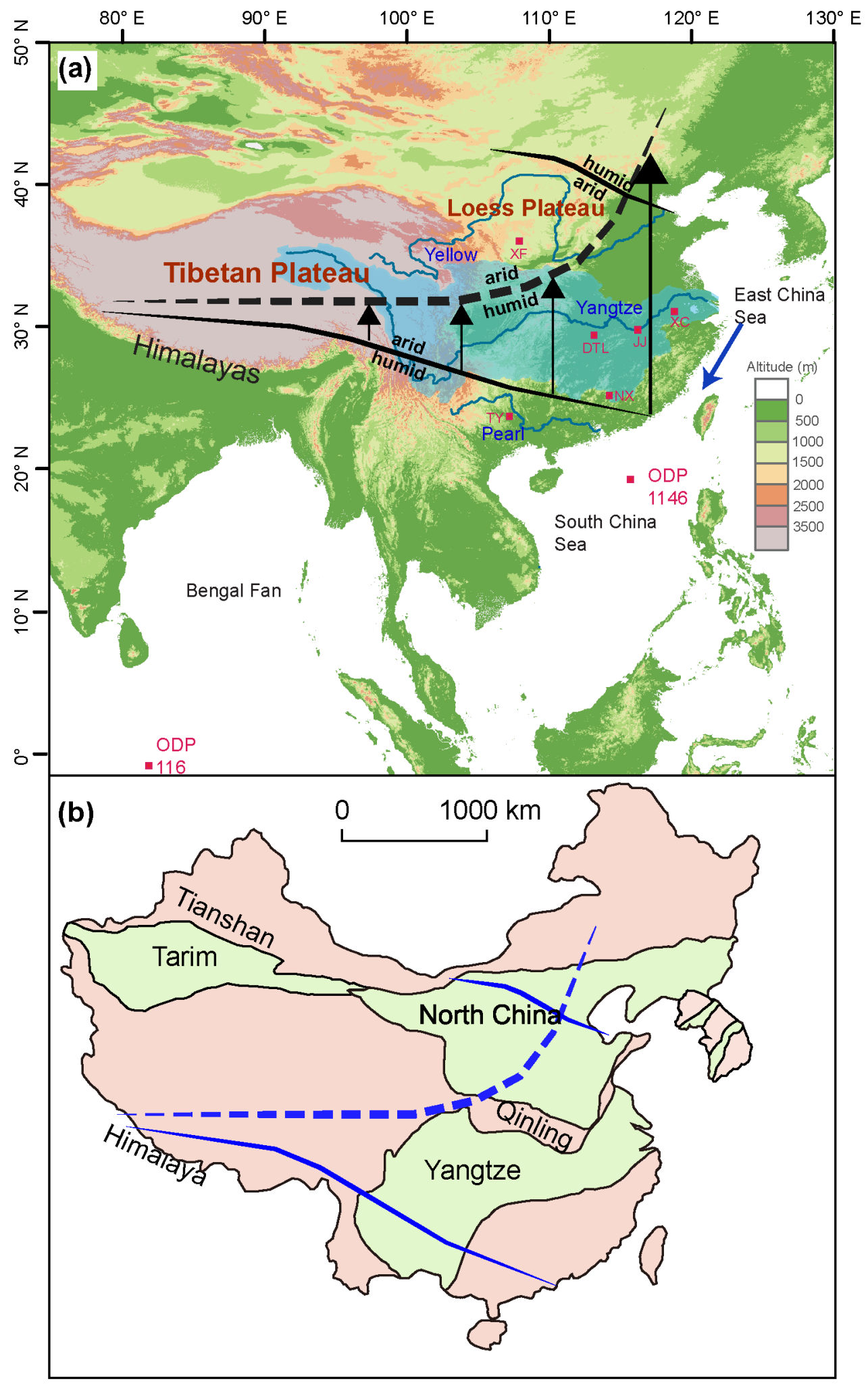

610 Figure 1 (a) Cenozoic humid/arid boundaries in China for the Palaeogene (black bold 611 line) and the Neogene to Quaternary (black dashed line). Black arrows show the 612 northward migration of the humid zone. Red squares are locations of the studied soils 613 (XF, Xifeng loess; DTL, Dongting Lake, JJ, Jiujiang; XC, Xuancheng; NX, Nanxiong; 
614 and TY, Tianyang) and sediments (ODP site 1146 in the South China Sea, SCS; ODP 615 site 116 in the Bengal Fan). The light blue shaded area marks the drainage area of the 616 Yangtze River. The blue arrow shows the modern transport path of sediments from the 617 Yangtze River mouth to the SCS (Liu et al., 2003). (b) Simplified tectonic map of the 618 Chinese continent showing the distributions of major cratons (green area) and orogens 619 (light brown area) (redrawn from Gao et al., 1998 and Zheng et al., 2013). Black lines 620 mark major faults. The northward migration of the humid zone (the area between the 621 blue bold and dashed lines) impacted the majority of the Yangtze craton. 



623 Figure 2 (a) Modern soil type distributions with isohyets ( $\mathrm{mm}$ ) in Asia. Soil type data 624 are based on the FAO-UNESCO Soil Map of the World 625 (http://www.fao.org/geonetwork/srv/en/main.home). (b) Soil organic carbon content $626(\%)$ distributions with isohyets $(\mathrm{mm})$ in China. Organic carbon data refer to surface 627 soil horizons (0 to $30 \mathrm{~cm}$ ) from Wieder et al. (2014). Isohyet data are from updated 628 high-resolution grids of monthly climatic observations acquired from the CRU TS 

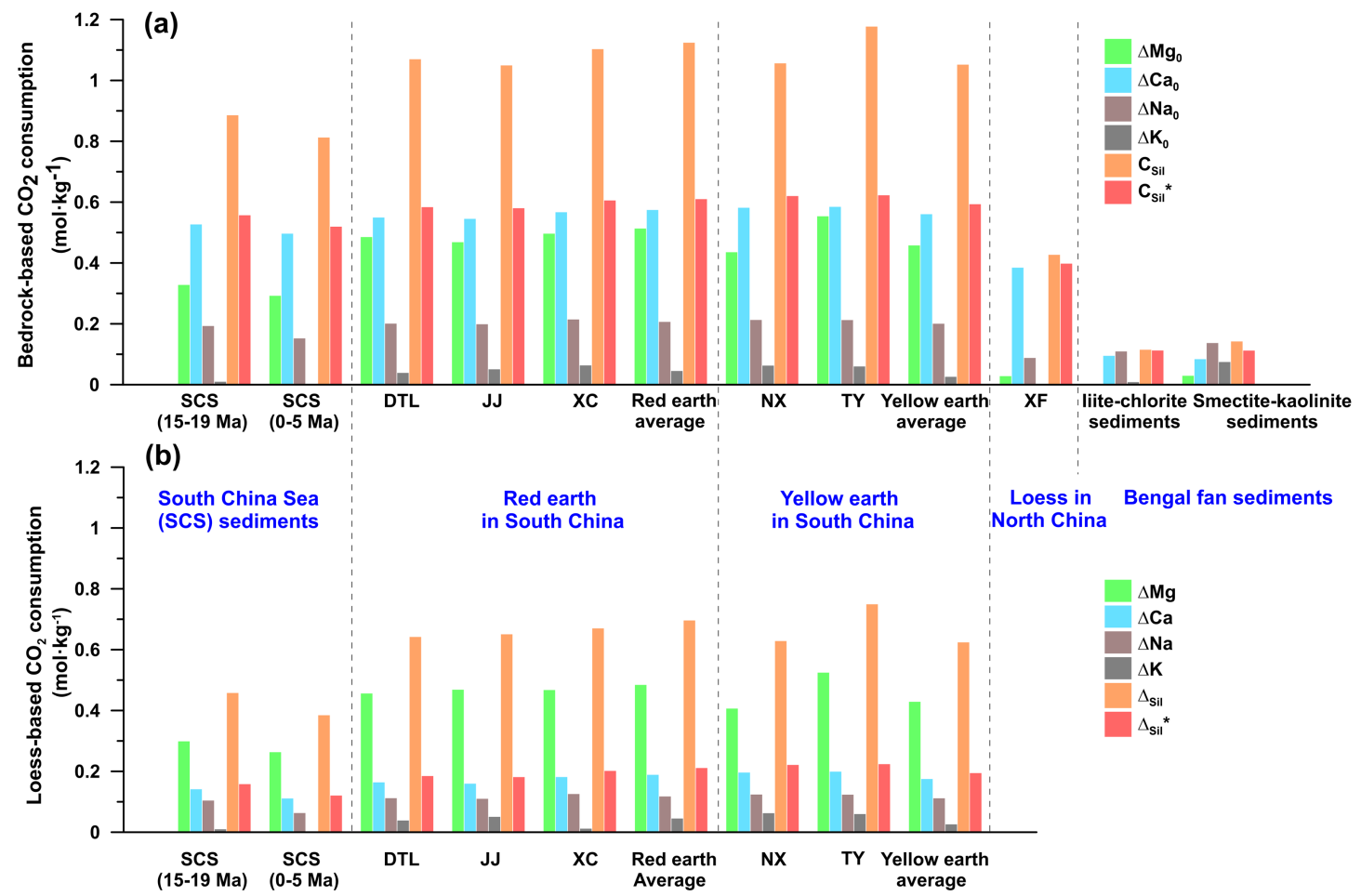

Figure 3 (a) Consumption of atmospheric $\mathrm{CO}_{2}$ by silicate weathering estimated from

632 the difference between the chemistry of various sediments and bedrock. The Bengal

633 Fan sediment composite is based on unaltered Himalayan source rocks

634 (France-Lanord and Derry, 1997); others are calculated based on the carbonate-free 635 upper crust of East China (Gao et al., 1998). (b) Difference in atmospheric $\mathrm{CO}_{2}$ 636 consumption by silicate weathering between various sediments used for the post-late 637 Oligocene monsoon-influenced region (sediments in the South China Sea 638 (SCS)/various soils in South China) and loess from Northwest China. 


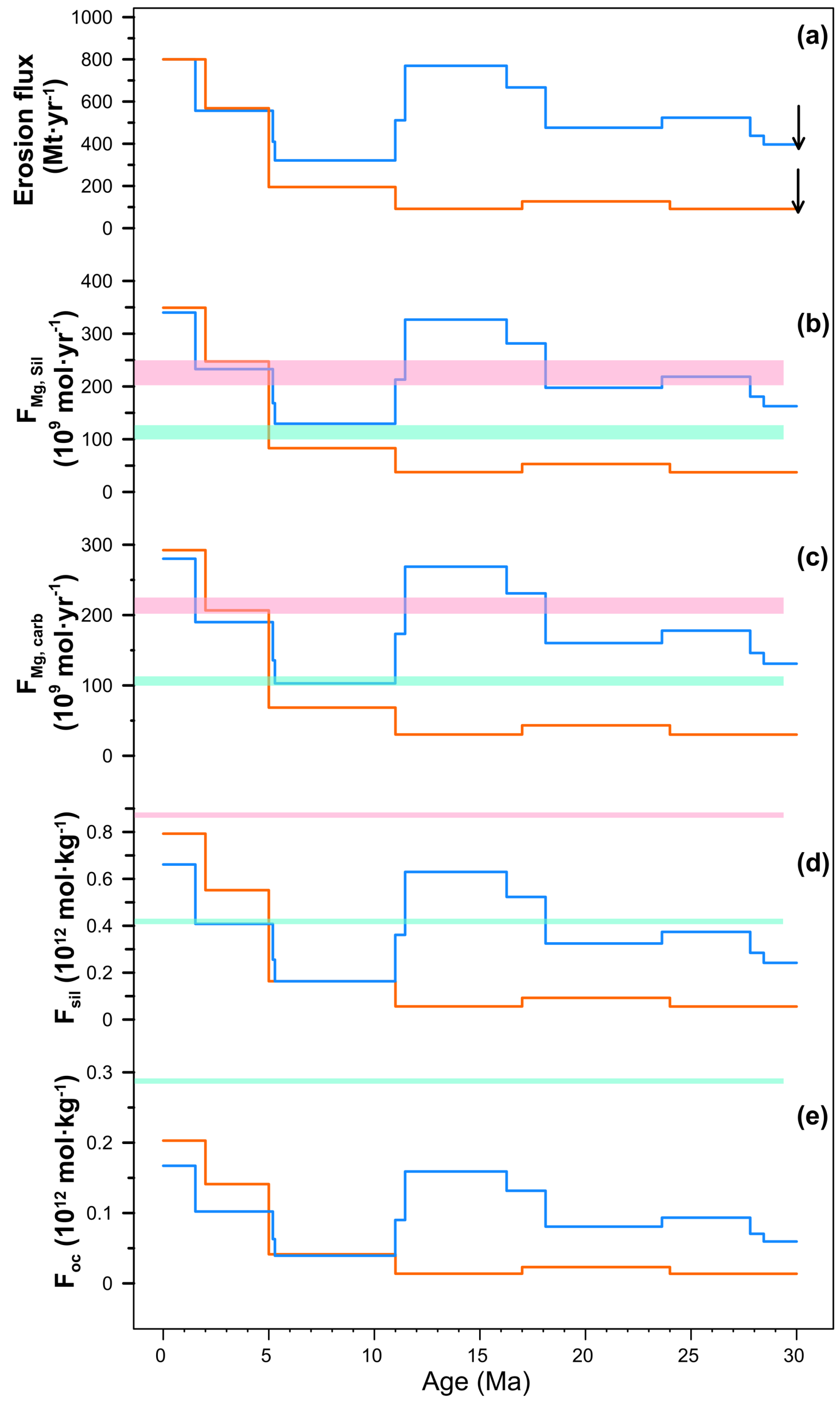


640 Figure 4 The estimated erosion flux (a), $\mathrm{CO}_{2}$ consumption flux (b), and $\mathrm{Mg}$ release 641 fluxes from weathering of silicate $\left(\mathrm{F}_{\mathrm{Mg}}\right.$, sil $)$ (c) and carbonate $\left(\mathrm{F}_{\mathrm{Mg}}\right.$, carb $)$ (d) as well as 642 organic burial flux (e(, related to late Oligocene monsoon advance in East Asia. The 643 orange and blue cruves in (a-e) are based on two reconstructed sediment discharge 644 fluxes based on the East China Platform dataset (Métivier et al., 1999) and integrative 645 flux of the Pearl River and East China Sea basins (Clift et al., 2004), respectively. 646 Curves in (b) were reconstructed by our estimated modern physical erosion flux of $647 \sim 800 \times 10^{6} \mathrm{t}^{\cdot} \mathrm{yr}^{-1}$ for the monsoon-influenced region by multiplying the relative 648 variations of two sediment discharge models. The black arrows in (b) mark the 649 erosion flux before the late Oligocene climatic reorganization. The pink and green 650 shaded areas in (b-e) mark the 10\% and 5\% levels of the modern flux for each panel, 651 respectively.

(a)

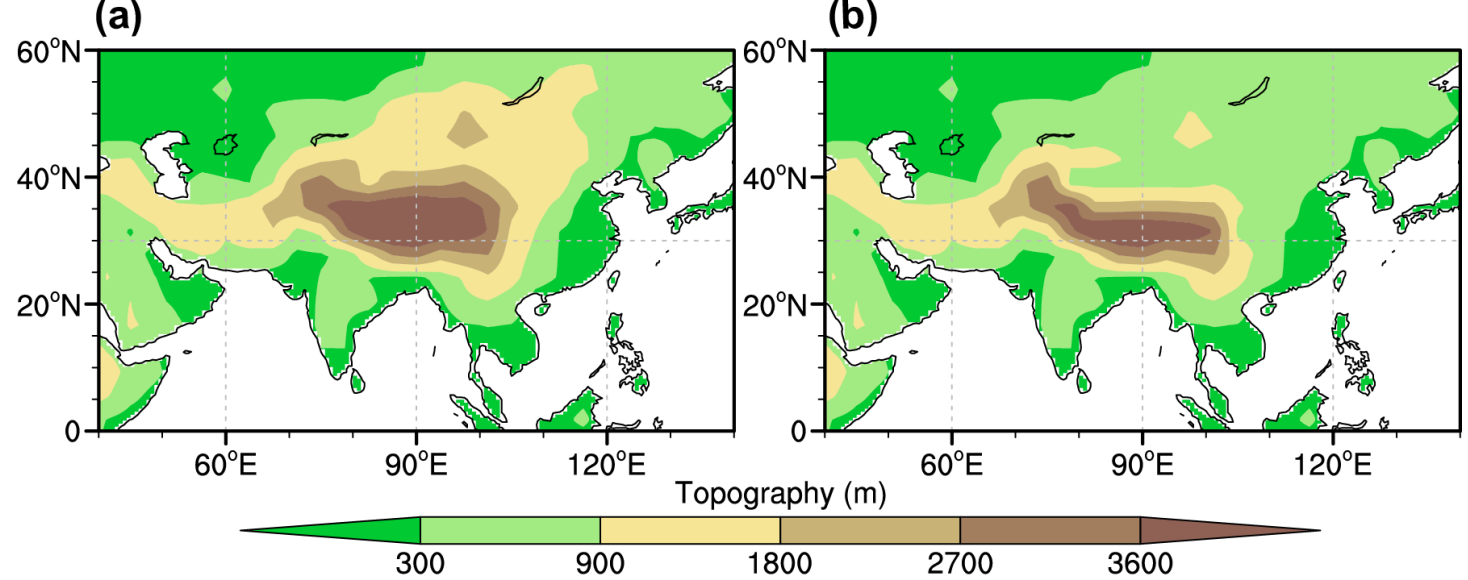

(c) Annual

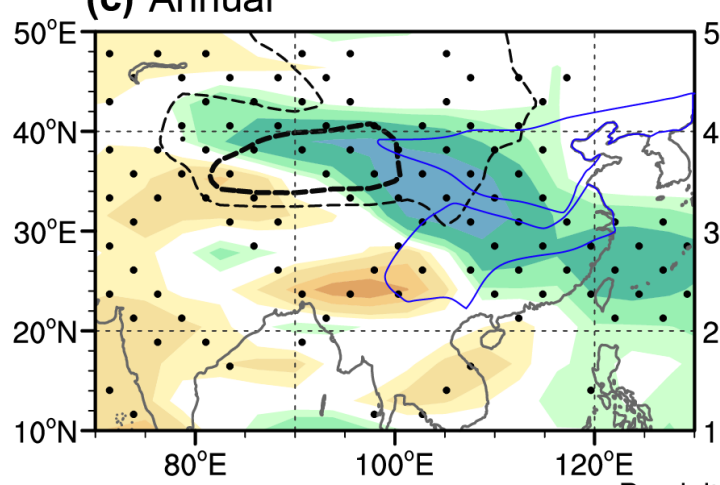

(d) Summer



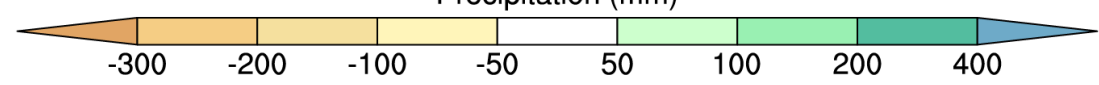

654 Figure 5 Modern topography (a) and removal of the northern Tibetan Plateau (b) over Asia. Differences in (c) annual precipitation (coloured areas) and (d) summer monsoon (May to September) precipitation (coloured areas) and $850 \mathrm{hPa}$ winds (red arrows) between the climate model experiments with the modern topography. Dotted areas correspond to places with confidence levels greater than 95\% (using Student's 
$659 t$-test) in precipitation change. The thick and thin black dashed lines mark the contour 660 lines of 500 and $1500 \mathrm{~m}$ for topography removal, respectively, of the northern Tibetan 661 Plateau between the two climate models. The blue lines indicate the contours of the 662 Yangtze and North China cratons. 